\title{
Effects of Plantain (Musa species) as Shade on the Growth Performance of Cocoa Seedlings in the Nursery at Ibadan, Southwest, Nigeria
}

Famaye Amos Olatunde, Iremiren Gerald Oaikhena, Akanbi Olorunfemi Sunday Ojo, Ayegbonyin Kayode Olufemi, Adejobi Kayode Babatunde

Cocoa Research Institute of Nigeria, Ibadan, Nigeria

Email: tunmos2010@yahoo.com, akanbioso2008@yahoo.com, akanbioso2008@gmail.com

Received 19 June 2013; revised 4 August 2013; accepted 2 September 2013

Copyright (C) 2014 by authors and Scientific Research Publishing Inc.

This work is licensed under the Creative Commons Attribution International License (CC BY).

http://creativecommons.org/licenses/by/4.0/

(c) (i) Open Access

\section{Abstract}

Nursery experiment was carried out at Ibadan, Nigeria between May 2004 and October 2005 to evaluate the use of plantain as a permanent cocoa nursery shade crop. Ibadan is located between latitude $07^{\circ} 10^{\prime} \mathrm{N}$ and longitude $03^{\circ} 52^{\prime} \mathrm{E}$ and lies at an altitude of about 122 metres above the sea level. The treatments consisted of six shade regimes provided by plantain spaced at 1.0, 1.5, 2.0, 2.5 and, $3.1 \mathrm{~m}$ apart, the control had no shade at all (open planted cocoa). Each treatment had one hundred cocoa seedlings planted in polythene bag filled with topsoil and laid out in a randomized complete block design (RCBD) in three replications. Data on vegetative growth of cocoa seedlings were taken on monthly basis, while plantain height, girth, number of leaves, bunch weight, number of fingers and market value of each treatment were evaluated. Light intensity under each of the treatment was taken using light meter. Result showed that cocoa seedlings under plantain shade planted at $1.0 \mathrm{~m}$ and $1.5 \mathrm{~m}$ apart were higher in height relative to control and other treatments considered, shade regimes provided by spacing at $3.1 \times 3.1 \mathrm{~m}$ and $2.5 \mathrm{~m} \times 2.5 \mathrm{~m}$ apart on the other hand produced higher values for stem diameter and leaf area respectively compared to other treatments, the least values were recorded under $1.0 \mathrm{~m} \times 1.0 \mathrm{~m}$ apart. Seedlings under $2.5 \mathrm{~m}$ and $3.1 \mathrm{~m}$ spacing were significantly $(\mathrm{p}>0.05)$ higher for these parameters than other treatments. Higher incidence of weed was also recorded from the control. Plantain bunch obtained from $2.5 \mathrm{~m}$ and $3.1 \mathrm{~m}$ apart was higher than other treatments in terms of weight, number of fingers and market value, while the control (no plantain shade) did not give any economic returns. Hence, plantain planted at spacing of $2.5 \mathrm{~m}$ or $3.1 \mathrm{~m}$ apart could be recommended to the cocoa farmers in Nigeria as nursery shade instead of conventional method of using bamboo and palm fronds yearly without any additional economic return. 


\section{Keywords}

\section{Musa Species, Evaluation, Plantain, Cocoa, Nursery}

\section{Introduction}

The nursery is the place where the cocoa beans are germinated as soon as they are harvested and where the young plants are raised for at least five months with a view to planting them out in the field. It is a very important place upon which the success or failure of plantation to a large extent depends. Farmers in Nigeria could not afford artificial nurseries shade for their cocoa because of the prohibitive cost of these materials and none readily available at farmer disposal. Research on the use of shade for Cocoa started in West Indices. Cocoa can be established under thinned forest or under temporary life shade (Opeke, 1982). Shade had been reported to protect Cocoa plant from harmful effects of direct insolation and minimize the risk of leaf and branch scorch by establishing a more equitable eco-climate through the reduction of high intensity, temperature and air movement. According to Opeke (1982) provision of good shade enhances survival of cocoa seedlings during the dry season. The need for traditional shade in the present day of Tea, Coffee and most especially in Cocoa is frequently questioned. In Tea garden of North Indian, shading is still considered essential while in other areas such as in the Tea and Coffee plantations of East Africa; its use is rapidly diminishing. However, the usual way of providing the shade required for cocoa nursery by cocoa farmers in Nigeria is building annually a framework of wooden or bamboo pole ( $3 \mathrm{~m}$ high) which will support shading at a height of $2.5 \mathrm{~m}$ from the ground, letting through approximately 50 percent of light intensity. Palm frond is usually used in creating this shade. In several countries, shading of the nursery is achieved using various permanent plants such as Hevea, the oil palm or Gliricida [1]. Plantains have been found to provide 50 percent light intensity required for coffee at the early stage of field establishment [2]. Plantain is a fast growing crop with good shade which always serves as source of food and also brings economic returns to farmers when the bunches and suckers are sold. Cocoa farmers in Nigeria used plantain as nursery shade for the establishment of their cocoa on the field. The objective of this study therefore is to evaluate plantain as shade crop for permanent cocoa nursery.

\section{Materials and Methods}

\subsection{Description of the Site Used for the Experiment}

The experiment was conducted in the central nursery of Cocoa Research Institute of Nigeria, Ibadan during the $2004 / 2005$ cropping season. Ibadan is located between latitude $07^{\circ} 10^{\prime} \mathrm{N}$ and longitude $03^{\circ} 52^{\prime} \mathrm{E}$. It lies at an altitude of about 122 metres above the sea level with the total annual rainfall of about $1100 \mathrm{~mm}$ to $1250 \mathrm{~mm}$, distributed over a period of between nine to ten months in a bimodal rainfall pattern. Early rain occurs between March to July and late rain occurs between August to October with five months of dry season and a short dry spell in August. The temperature of Ibadan is fairly high throughout the year with maximum temperature usually ranges between $26^{\circ} \mathrm{C}$ to $35^{\circ} \mathrm{C}$ with an average of about $30.1^{\circ} \mathrm{C}$ while the minimum temperature ranges between $15^{\circ} \mathrm{C}$ to $24^{\circ} \mathrm{C}$ with an average of $19.5^{\circ} \mathrm{C}$. Ibadan has a moderately high to very high relative humidity throughout the months of the year with an average of $79.06 \%$, the soil temperature is fairly high with an average temperature of $28.8^{\circ} \mathrm{C}$.

\subsection{Land Preparation, Field Layout and Treatments Imposition}

The land was manually cleared, tree felled, trash and tree logs packed. Holing and planting of plantain suckers which were obtained from the C.R.I.N nursery was done was done immediately after field layout was completed six months before seedlings were transferred and arranged under the plantains of different spacing and shade regimes. The treatments comprised six shade regimes provided by plantains planted at1.0, 1.5, 2.0, 2.5 and $3.1 \mathrm{~m}$ apart, arranged in a Randomized complete block design (RCBD) in three replications. The control treatment involves no shading. There were twenty (20) polythene bags representing each of the treatment given a total number of one hundred and twenty (120) polythene bags altogether filled with top soil collected from the experimental site. Two (2) cocoa beans each was sown per polythene bag and later thinned to one (1) vigorous seedling 
per bag and later transferred to the field. Data collected were plant height, girth, leaf number and leaf area for cocoa seedlings and plantain as well as plantain bunch yield. The light intensity was monitored per treatment using a light meter.

\subsection{Laboratory Analysis}

Prior to the sowing of the cocoa beans, surface soil samples $(0-20 \mathrm{~cm})$ were taken from the experimental site for physical and chemical analysis. The samples were air dried, sieved through a $2 \mathrm{~mm}$ sieve and analyzed for physical and chemical properties. Prior to the sowing of the cocoa beans, surface soil samples $(0-20 \mathrm{~cm})$ were taken from the experimental site for physical and chemical analysis. The samples were air dried, sieved through a $2 \mathrm{~mm}$ sieve and analyzed for physical and chemical properties. Total $\mathrm{N}$ of the soil was determined by MicroKjeldah method and the available $\mathrm{P}$ was by Bray 1 method [3]. The cations were extracted by $1 \mathrm{NH}_{4} \mathrm{OAC}$ at $\mathrm{pH}$ 7 and the $\mathrm{K}, \mathrm{Ca}$ and $\mathrm{Mg}$ contents were read using atomic absorption spectrometer (AAS). The OC was determined by wet dichromate oxidation method [4]. Particle size distribution was determined by the hydrometer method [5] using sodium hexameter-phosphate as the dispensing agent. Soil $\mathrm{pH}$ was determined potentio-meterically in distilled water at soil to water ratio 1:1.

\subsection{Statistical Analysis}

The results obtained were subjected to statistical analysis of variance and LSD was used to separate the means.

\section{Results}

The result of soil analysis of the experimental site revealed that the soil from the field is moderately acidic with the $\mathrm{pH}$ value of 6.10 (Table 1 ). This generally falls within 6.0 - 6.5 reported to be normal for tree crops in Nigeria [6] and [7]. Based on the data, the soil $\mathrm{pH}$ is adequate for optimal microbial activities in the soils and ease of nutrient release for crop usage.

The available $\mathrm{P}$ content of $11.10 \mathrm{mg} \cdot \mathrm{kg}^{-1}$ soil was found to be adequate and higher than the critical values calculated for tree crops [8]. The soil potassium (K) content is found to be moderately available. The moderately available $\mathrm{K}$ value of the field must have been as a result of continuous deposit through leaf litter falls over time. Similarly, the soil calcium Ca content of $4.98 \mathrm{cmol} \cdot \mathrm{kg}^{1}$ was fairly moderate in the soil although slightly lower than the critical value of $5.0 \mathrm{cmol} \cdot \mathrm{kg}^{-1}$ soil which is considered ideal for cocoa production. The soil organic carbon content and total nitrogen $(\mathrm{N})$ were also found to be slightly moderate when compared with the soil critical values of 30.0 and $0.9 \mathrm{~g} / \mathrm{kg}$ soil. Soil $\mathrm{Mg}$ contents of the site was $5.31 \mathrm{cmol} \cdot \mathrm{kg}^{-1}$ soil (Table 1 ). This value is grossly lower than the critical values of $8.0 \mathrm{~g} \mathrm{cmol} \cdot \mathrm{kg}^{-1}$ soil. Magnesium based fertilizer is therefore needed for the soils to supply enough Mg to the planted cocoa seedling. The results of the physical properties analysis indicated that the soil is generally sandy-loam in texture (Table 1). The Silt + Clay values of $350.0 \mathrm{~g} / \mathrm{kg}$ was higher than $320 \mathrm{~g} / \mathrm{kg}$ which is ideal for sufficient water holding capacity for sustainable cocoa growth without irrigation need [8].

Table 1. Physico-chemical properties of the experimental site used.

\begin{tabular}{|c|c|c|c|c|}
\hline \multirow{2}{*}{ Chemical } & \multicolumn{4}{|c|}{ Soil properties } \\
\hline & Units & Values & Physical & Values (kg) \\
\hline pH $\left(\mathrm{H}_{2} \mathrm{O}\right)$ & & 6.1 & & \\
\hline Available Phosphorus & mg/kg & 11.1 & & \\
\hline Potassium & $\mathrm{cmol} / \mathrm{kg}$ & 2.98 & SILT & 247.8 \\
\hline Calcium & $\mathrm{cmol} / \mathrm{kg}$ & 4.98 & CLAY & 102.32 \\
\hline Magnesium & $\mathrm{cmol} / \mathrm{kg}$ & 5.31 & SAND & 649 \\
\hline Nitrogen & $\mathrm{g} / \mathrm{kg}$ & 0.88 & TEXTURAL CLASS & Sandy loam \\
\hline Organic Carbon. & $\mathrm{g} / \mathrm{kg}$ & 29.86 & & \\
\hline
\end{tabular}


Results obtained on plant height are presented in Table 2. Plant height of cocoa seedlings were significantly $(p>0.05)$ influenced by shade regimes. The highest cocoa seedling height $(\mathrm{cm})$ was recorded under plantain planted at $1 \mathrm{~m} \times 1 \mathrm{~m}$ apart; this was followed by cocoa under shade regime provided by plantain planted at 1.5 $\mathrm{m}$ apart. Cocoa seedlings planted under no shade (control) recorded the least plant height.

The differences were significant. Cocoa seedlings under shade regime provided by plantain planted at $3 \mathrm{~m}$ apart were not different significantly compare to the control at one month after transplanting. At 2nd, 3rd, 4th and 5th months after sowing, the plant height of cocoa seedlings under shade regime provided by plantain at 1.0, 1.5 and $2.0 \mathrm{~m}$ apart gave a significantly higher plant height relative to control. The differences in plant height of cocoa seedlings under shade regimes provided by $2.5 \mathrm{~m}, 3.0 \mathrm{~m}$ and control (no shade) respectively were not significantly different from each other throughout the period under consideration.

Table 3 presents data on stem diameter of cocoa seedlings as influenced by different shade regimes provided by plantain at $3.0 \mathrm{~m} \times 3.0 \mathrm{~m}$ apart. Cocoa seedlings planted under wider spacing $(3 \mathrm{~m} \times 3 \mathrm{~m})$ produced highest and significant $(\mathrm{p}>0.05)$ mean stem diameter values relative to control and other shade regimes provided by plantain planted at closer spacing of $1.0 \mathrm{~m}$ and $1.5 \mathrm{~m}$ apart respectively produced the least mean values of stem diameter. The differences in stem diameters of cocoa seedlings under shade regimes provided by plantain at 1.0 and $1.5 \mathrm{~m}$ apart respectively were not significantly $(\mathrm{p}>0.05)$ different at first and second months after planting. Similarly, the differences recorded by shade regimes provided by plantain at 2.0, 2.5, 3.0 and control (no shading) were not significant although, there appears to be a slight increases across the various treatments at 2 months after planting. At 3, 4 and 5 months after planting, the results obtained were similar to the previous months. Shade regime provided by plantain at $3.0 \mathrm{~m}$ apart recorded highest mean values of stem diameter while shade regimes provided by plantain at closer $(1.0 \mathrm{~m})$ spacing recorded the least mean values. While the differences between $1.0 \mathrm{~m}$ and $2.0 \mathrm{~m}$ are comparable, the rest are significantly higher relative to control.

Table 2. Plant height (cm) of cocoa seedlings as influenced by different shade regimes in the nursery.

\begin{tabular}{|c|c|c|c|c|c|}
\hline \multirow{2}{*}{ Treatments } & \multicolumn{5}{|c|}{ Months after sowing } \\
\hline & 1 & 2 & 3 & 4 & 5 \\
\hline $1.0 \mathrm{~m}$ apart & 27.0 & 30.0 & 32.0 & 34.0 & 36.0 \\
\hline $1.5 \mathrm{~m}^{\prime}$ & 23.0 & 28.0 & 31.9 & 33.9 & 36.4 \\
\hline $2.0 \mathrm{~m}^{\prime}$ & 22.0 & 25.0 & 27.4 & 32.1 & 33.2 \\
\hline $2.5 \mathrm{~m}^{\circ}$ & 21.0 & 23.0 & 27.4 & 28.7 & 29.7 \\
\hline $3.0 \mathrm{~m}$ “ & 18.0 & 20.0 & 22.1 & 25.9 & 26.2 \\
\hline Control & 17.0 & 19.0 & 21.1 & 23.7 & 24.5 \\
\hline LSD $(p<0.05)$ & 3.46 & 4.67 & 5.17 & 5.8 & 5.3 \\
\hline
\end{tabular}

Table 3. Mean stem diameter (mm) of Cocoa seedlings as affected by different shade regimes.

\begin{tabular}{|c|c|c|c|c|c|}
\hline \multirow{2}{*}{ Treatments } & \multicolumn{5}{|c|}{ Months after sowing } \\
\hline & 1 & 2 & 3 & 4 & 5 \\
\hline $1.0 \mathrm{~m}$ apart & 0.46 & 0.54 & 0.56 & 0.63 & 0.66 \\
\hline $1.5 \mathrm{~m}$ “ & 0.47 & 0.55 & 0.60 & 0.72 & 0.75 \\
\hline $2.0 \mathrm{~m}$ “ & 0.51 & 0.64 & 0.66 & 0.78 & 0.80 \\
\hline $2.5 \mathrm{~m}^{\prime}$ & 0.52 & 0.64 & 0.70 & 0.80 & 0.81 \\
\hline $3.0 \mathrm{~m}^{\prime \prime}$ & 0.55 & 0.67 & 0.79 & 1.04 & 1.06 \\
\hline Control & 0.54 & 0.66 & 0.77 & 0.84 & 0.86 \\
\hline LSD $(p<0.05)$ & 0.04 & 0.06 & 0.10 & 0.14 & 0.14 \\
\hline
\end{tabular}


Table 4 presents data on leaf area $\left(\mathrm{cm}^{2}\right)$ as influenced by shade regime. Similar trend was observed for leaf area of cocoa seedlings throughout the period of the experiment. Cocoa seedlings planted under shade regime provided by plantain planted at a wider spacing of $3 \mathrm{~m}$ apart produced broader leaves and recorded the highest leaf area () $\mathrm{cm}^{2}$ values, while the lowest value was recorded under closely spaced plantain of $1.0 \mathrm{~m}$ apart. Leaf area under wider spacing $(3 \mathrm{~m} \times 3 \mathrm{~m}$ apart) significantly $(\mathrm{p}>0.05)$ and consistently improved leaf area of cocoa seedlings relative to control and other treatments considered.

Table 5 showed the mean growth parameter of plantain at different planting distances. Plantain planted at a spacing of $1 \mathrm{~m} \times 1 \mathrm{~m}$ apart gave the highest plant height $(\mathrm{cm})$ and mean number of leaves per plant respectively; this was followed by those planted at $1.5 \mathrm{~m}$ apart. Plantain spaced at $3.0 \times 3.0 \mathrm{~m}$ apart recorded the least plant height. The mean number of leaves recorded by plantain spaced at $1 \mathrm{~m}$ apart was significantly higher than the rest. Conversely, stem diameter of plantain planted a wider spacing of $3.0 \mathrm{~m} \times 3.0 \mathrm{~m}$ apart produced thicker and wider stem diameter compared to other planting distances. Plantain spaced at a distance of $1.5 \mathrm{~m}$ and $2.0 \mathrm{~m}$ apart are not significantly $(\mathrm{p}>0.05)$ different from each other. Also, the mean diameter produced by plantain at $2.0 \mathrm{~m}$ $\times 2.5 \mathrm{~m}$ apart respectively are not significantly different $(\mathrm{p}>0.05)$ from each other.

The number of plantain fingers, fresh weight of plantain bunches and selling price is presented in Table 6 . The results indicated that plantains spaced at $3.0 \mathrm{~m}$ apart produced more number of harvested plantain bunches compared to other treatments. In terms of total fresh weight of harvested bunches (kg), the plantains at $3.0 \mathrm{~m} \times$ $3.0 \mathrm{~m}$ apart gave the highest mean weight and total number of plantain fingers. This was followed by those planted at $2.5 \mathrm{~m}$ and $2.0 \mathrm{~m}$ apart. The highest selling price was obtained from plantain at $3.0 \mathrm{~m}$ apart which was followed by those planted at a spacing of $2.5 \mathrm{~m}$ apart. Generally, the higher values in growth parameters (plant height, numbers of leaves, stem diameter, leaf area etc.) recorded for cocoa seedlings and yield data for plantain under spacing at $3 \mathrm{~m} \times 3 \mathrm{~m}$ and $2.5 \mathrm{~m} \times 2.5 \mathrm{~m}$ apart might have been due to shading effect received from plantain that moderated the amount of insolation and temperature in the nursery to the advantage of the crop for optimum the photosynthetic activities. This agreed with the findings of [6] and [9] who reported such beneficial

Table 4. Mean Leaf area (cm2) of cocoa seedlings under different spacing of plantain as nursery shade.

\begin{tabular}{cccccc}
\hline & \multicolumn{5}{c}{ Months after sowing } \\
Treatments & $\mathbf{1}$ & $\mathbf{2}$ & $\mathbf{3}$ & $\mathbf{4}$ & $\mathbf{5}$ \\
\cline { 2 - 6 } & 54.31 & 62.15 & 82.15 & 100.64 & 113.13 \\
\hline $\mathbf{1 . 0} \mathbf{~ m}$ apart & 56.50 & 73.76 & 90.73 & 120.11 & 121.79 \\
$\mathbf{1 . 5} \mathbf{~ m}$ “ & 60.00 & 80.87 & 102.51 & 130.22 & 133.12 \\
$\mathbf{2 . 0} \mathbf{~ m}$ “ & 63.95 & 90.56 & 116.06 & 148.65 & 150.72 \\
$\mathbf{2 . 5} \mathbf{~ m}$ “ & 77.74 & 133.55 & 202.29 & 284.00 & 263.05 \\
$\mathbf{3 . 0} \mathbf{~ m}$ “ & 66.95 & 100.44 & 162.09 & 110.64 & 115.05 \\
Control & 4.58 & 22.14 & 22.14 & 41.06 & 43.49 \\
\hline LSD (p $<$ 0.05) & & & & \\
\hline
\end{tabular}

Table 5. Agronomic parameter as influenced by different shade regimes.

\begin{tabular}{cccc}
\hline \multirow{2}{*}{ Treatments } & \multicolumn{2}{c}{ Agronomic parameter } & \\
\cline { 2 - 4 } & MPH (cm) & MPG (cm) & MNL \\
\hline $\mathbf{1 . 0}$ m apart & 64.50 & 455 & 11 \\
$\mathbf{1 . 5}$ m“ & 69.25 & 440 & 11 \\
$\mathbf{2 . 0}$ m“ & 69.75 & 416 & 10 \\
2.5 m“ & 74.25 & 410 & 10 \\
$\mathbf{3 . 0}$ m“ & 75.75 & 375 & 10 \\
LSD (p $\mathbf{0 . 0 5})$ & 4.95 & 34 & 0.4 \\
\hline
\end{tabular}

MPH = Mean plant height, MPG =; Mean plant girth, MNL = Mean number of leaves. 
Table 6. Economic yield of Plantains in 2005/2006 cropping season.

\begin{tabular}{ccccc}
\hline & \multicolumn{4}{c}{ Economic yield of plantain } \\
Treatments & NBP & NPF & FWB (kg) & PHB (N) \\
\cline { 2 - 4 } & 12 & 290 & 77.9 & 3680 \\
$\mathbf{1 . 0}$ m apart & 12 & 374 & 85.3 & 3830 \\
$\mathbf{1 . 5}$ m“ & 13 & 450 & 97 & 4050 \\
$\mathbf{2 . 0}$ m“ & 13 & 400 & 104 & 5200 \\
$\mathbf{2 . 5}$ m“ & 17 & 488 & 121 & 4510 \\
$\mathbf{3 . 0}$ m“ & 2.6 & 84.0 & 18.4 & 683 \\
\hline
\end{tabular}

$\mathrm{m}=$ metre, $\mathrm{kg}=$ kilogramme, $\mathrm{NBP}=$ number of bunches produced, NPF = Number of plantain fingers, FBW = fresh weight of bunch.

effects from cocoa nursery when light intensity is 50 percent. Studies have also confirmed that planting of plantain at a distant of $3 \mathrm{~m} \times 3 \mathrm{~m}$ cast the required shade for good cocoa growth and provide a light intensity of about $50 \%$ which proved to be the best.

\section{Discussion}

Shade cast provided by plantain significantly enhanced the growth parameters of Cocoa (plant height, leaf area, number of leaves and stem girth) seedlings. This observation is in agreement with the findings of [10] who observed that plant raised under 50\% shade produced taller with more leaves and higher dry matter yield than the unshaded clones. The better performance and/or the behavior of the Cocoa seedlings under the plantain planted at $3 \mathrm{~m} \times 3 \mathrm{~m}$ which was found to cast about $50 \%$ shade on the crop might be due to high assimilation rate of the cocoa seedlings under this condition, this is also in agreement with the earlier work of [11] who reported that the rate of assimilation of Arabica coffee was found to be greater under condition of moderate light intensity than in full sunshine and that the total daily assimilation rate is greater under the shade than in the sun. The overall water requirement of the crop and consequently diminishes the likelihood of water stress he concluded.

\section{Conclusion}

Considering the good growth performance recorded for cocoa seedlings planted at $3 \mathrm{~m}$ and $2.5 \mathrm{~m}$ apart as well as the economic returns from the said plantain, it is therefore recommended that plantain be planted at a planting distance of either $2.5 \mathrm{~m}$ or $3.0 \mathrm{~m}$ apart. The choice of plantain as a permanent shade crop under cocoa plantation by Cocoa farmers will go a long way in helping the poor and low-income peasant farmers in meeting some of their day to day running expenses in the first two to three years of their investment as Cocoa farmers.

\section{References}

[1] Coste, R. (1992) Coffee: The Plant and Products. Macmillan Press Ltd., London, 328p.

[2] Famaye, A.O. (2000) Effect of Shade Regimes on Growth and Nutrient Uptake of Seedling and on Matured Tree of Coffee Species in Nigeria. PhD Thesis, University of Ibadan, Ibadan, 223p.

[3] Bray, R.A. and Kurtz, L.T. (1945) Determination of Total Organic and Available Forms of Phosphorus in Soils. Soil Science, 59, 39-45. http://dx.doi.org/10.1097/00010694-194501000-00006

[4] Nelson, D.W. and Somers (1982) Organic Carbon and Soil Extracts. Methods of Soil Analysis. Part 2-Chemical and Microbiological Properties. Agronomy, Soil Science Society of America, Madison, 539-579.

[5] Udo, E.J. and Ogunwale, J.O. (1986) Laboratory Manual for the Analysis of Soil, Plant and Water Samples. 2nd Edition, Department of Agronomy, University of Ibadan, Nigeria.

[6] Opeke, L.K. (1987) Tropical Tree Crops. John Willey and Sons Ltd., New York, 321p.

[7] Wood, G.A.R. and Lass, R.A. (1985) Cocoa. 4th Edition, Longman, London, 620-632.

[8] Egbe, N.E., Ayodele, E.A. and Obatolu, C.R. (1989) Fertilizer Use on Production of Cocoa, Kola, Coffee, Cashew and Tea in Nigeria. In: Progress in Tree Crop Research, 2nd Edition, Cocoa Research Institute of Nigeria, Ibadan, 28-38. 
[9] Are, L.A. and Adenikinju, S.A. (1967) CRIN-MANR Establishment Trials. 1965/1966 Annual Report, Cocoa Research Institute of Nigeria, Ibadan.

[10] Van Eijnattern, C.M. (1966) Kola. Annual Report. Cocoa Research Institute of Nigeria, Ibadan, 1965/66.

[11] Obatolu, C.R (1988) Soil Supporting Tea (Camellia sinensis) and Arabica Coffee Cultivated in Nigeria. The 1st All African Soil Science Society Congress, Kampala, 5-10 December 1988, 18p. 